\title{
Pendampingan Penanggulangan dan Penyelesaian Kasus Adopsi Anak dan Tindak Kekerasan dalam Rumah Tangga
}

\section{The Assistance of Countermeasures and Settlements of Children Adoption Case and the Domestic Violence}

\author{
Nanik Prasetyoningsih, Tanto Lailam \\ Universitas Muhammadiyah Yogyakarta, Yogyakarta \\ nprasetyoningsih@gmail.com, tanto.tatanegara@gmail.com
}

Riwayat Artikel: Dikirim 20 September 2018; Diterima 28 November; Diterbitkan 30 November

\begin{abstract}
Abstrak
Masyarakat Dusun Kemiri masih sangat perlu disosialisasi mengenai tatacara adopsi anak yang sesuai dengan peraturan perundang-undangan dan penanganan tindak kekerasan dalam rumah tangga. Pengabdian dilakukan dengan maksud untuk memberikan informasi yang akurat untuk meningkatkan pemahaman masyarat Dusun Kemiri mengenai adopsi anak dan penanganan kasus kekerasan dalam rumah tangga. Permasalahan yang ditemukan adalah sebagai berikut: (1) proses adopsi anak dilakukan berdasarkan kebiasaan yang berlaku di masyarakat, (2) kesadaran masyarakat masih rendah mengenai pentingnya bukti formal adopsi anak; (3) ketidakjelasan status anak adopsi menimbulkan tindak kekerasan dalam rumah tangga; dan (4) kasus kekerasan dalam rumah tangga masih belum belum teratasi dan terselesaikan. Metode pelaksanaan pengabdian adalah sebagai berikut: (1) melakukan sosialisasi tata cara adopsi anak sesuai hukum Indonesia; (2) melakukan sosialisasi penanggulangan kekerasan dalam rumah tangga; (3) melakukan Pelatihan dan Pembentukan Kader Pelindung Anak dan Satgas Anti kekerasan dalam rumah tangga; dan melakukan pendampingan Penyelesaian Kasus Adopsi Anak dan Kasus kekerasan dalam rumah tangga. Simpulan yang dapat diambil dari pelaksanaan pengabdian masyarakat adalah semua program kegiatan yang direncanakan telah terrealisasi dengan baik dan sesuai dengan jadwal dan rancangan yang telah ditentukan. Permasalahan adopsi anak sudah terpecahkan melalui beberapa tahap pengabdian. Demikianhalnya dengan penanganan Kasus kekerasan dalam rumah tangga. Pengabdian ini telah memberikan pemahaman yang komprehensif mengenai tata cara adopsi anak dan perlindungan kekerasan dalam rumah tangga. Pemahaman hukum dan kesadaran hukum mulai meningkat dan terjaga, karena senantiasa ada Kader Perlindungan Anak dan Satgas Anti kekerasan dalam rumah tangga yang aktif melakukan sosialisasi dan upaya-upaya penyadaran sosial bagi masyarakat.
\end{abstract}

Kata kunci: adopsi anak; kekerasan dalam rumah tangga; perlindungan hukum

\begin{abstract}
The Kemiri Village community still needs to socialize children's adoption procedures by the laws and the settlement of a domestic violence. The community service is carried out with the intention to provide accurate information to improve public understanding of the villagers regarding the adoption of children and handling the domestic violence. The problems found are as follows: the process of adoption of children based on the prevailing habits in the community, public awareness did not aware the importance of legalization of the children adoption; the unclear status of adopted children causes domestic violence, and the domestic violence cases are still not resolved. The implementation methods of service are as follows: disseminating procedures for adoption of children according to Indonesian law; socializing the prevention of domestic violence; training and Establishment of Child Protective Cadres and Task. Force on Domestic Violence; and assisting in the completion of cases of child adoption and cases of domestic violence. The conclusion of the implementation of the community service is that all planned activities have been realized following the predetermined schedule and design. The problem of adoption of children has been solved through several stages of activities, either the handling of domestic violence. This service has provided a comprehensive understanding of the procedures for adoption of children and protection of domestic violence. Legal understanding and legal awareness begin to increase and be maintained because there is always a Child Protection Cadre and Anti-violence Task. Force in the household that actively conducts socialization and social awareness efforts.
\end{abstract}

Keywords: the children adoption, domestic violence, the protection of law 


\section{PENDAHULUAN}

Dusun Kemiri terletak di lereng Gunung Merapi, tepatnya $8 \mathrm{~km}$ dari puncak Gunung Merapi dari sisi Selatan. Dusun Kemiri merupakan bagian dari Desa Purwobinangun, Kecamatan Pakem, Kabupaten Sleman Provinsi Daerah Istimewa Yogyakarta. Dusun Kemiri terletak di zona utara topografi Slemat, yang merupakan wilayah kaki Gunung Merapi. Daerah ini memiliki ketinggian kurang lebih $950 \mathrm{~m}$ di atas permukaan laut. Lokasi Kantor Kelurahan adalah di balai Desa Purwobinangun. Dari data yang diperoleh berdasarkan observasi, Dusun Kemiri terdiri dari 6 RT yaitu RT 01, RT 02, RT 03, RT 04, RT 05 dan RT 06. Jumlah warga di Dusun Kemiri ada 200 kk.

Potensi Dusun Kemiri dapat dilihat dari beberapa aspek, antara lain: aspek fisik, kondisi sosial budaya, bidang keagamaan, Pendidikan, kondisi kelembagaan, dan kesehatan.

Dusun Kemiri dilihat dari aspek fisik sudah memiliki jalan yang sudah beraspal halus, walaupun berada di kaki Gunung Merapi. Dusun Kemiri memiliki fasilitas umum berupa dua masjid dan sebuah sekolah PAUD. Di dusun ini juga sudah ada air bersih yang cukup tersedia untuk kebutuhan sehari-hari, jaringan telefon selular serta warung makan. Kondisi fasilitas umum di Dusun Kemiri tergolong baik dan masih sangat layak tetapi masih kurang adanya penanda tempat. Jalan dusun di tiap RT sudah seluruhnya di aspal. Penerangan di jalanjalan dusun juga dalam kondisi baik.

Kondisi sosial budaya menunjukkan bahwa masyarakat Dusun Kemiri sebagian besar bermata pencaharian sebagai Petani salak, peternak sapi perah dan juga penambang pasir. Organisasi kemasyarakatan di Dusun Kemiri cukup baik. Hal ini bisa dilihat dari organisasi yang terbentuk seperti PKK, Senam Lansia, Posyandu, Karang taruna, dll. Di Dusun ini juga ada kelompok usaha yang mengolah susu sapi dan juga buah salah.
Kegiatan keagamaan di Dusun Kemiri berjalan dengan baik. Mayoritas masyarakat di Dusun Kemiri beragama Islam dan kegiatan keagamaan seperti TPA yang diadakan rutin seminggu 2 kali dan pengaiian ibu-ibu secara rutin diadakan tiap minggunya.

Tingkat pendidikan warga Dusun Kemiri sudah cukup baik. Hal tersebut dapat dilihat dari jumlah warga yang lulus pendidikan menengah dan melanjutkan ke pendidikan tinggi. Pendidikan untuk anak usia dini juga diadakan di Dusun Kemiri. Terdapat sebuah PAUD yang berada di Dusun Kemiri dan merupakan tempat belajar anak usia dini di wilayah tersebut.

Kondisi Kelembagaan Dusun Kemiri dikepalai oleh seorang dukuh. Dusun Kemiri terdiri 6 RT yaitu RT 01, RT 02, RT 03, RT 04, RT 05 dan RT 06. Adapun lembaga lain yang ada di Dusun Kemiri yaitu Karang Taruna, Kelompok Tani dan Posyandu.

Kesehatan masyarakat Dusun Kemiri masih menggunakan fasilitas dari desa. Kegiatan posyandu yang berlangsung setiap setiap bulan di dusun tersebut.

Terkait dengan tema pengabdian masyarakat, ternyata di masyarakat Dusun Kemiri masih sangat perlu disosialisasi mengenai tatacara adopsi anak yang sesuai dengan peraturan perundang-undangan yang berlaku dan penanganan tindak kekerasan dalam rumah tangga. Pengabdian dilakukan dengan maksud untuk memberikan informasi yang akurat untuk meningkatkan pemahaman masyarat Dusun Kemiri mengenai adopsi anak dan penanganan kasus kekerasan dalam rumah tangga.

Dalam tabel di bawah ini ditemukan beberapa permasalahan dan usulan usulan penyelesaian permasalahan. Dalam setiap penyelesaian permasalahan, masyarakat akan selalu dilibatkan agar supaya lebih mengetahui permasalahan yang ada dan cara penanganannya. Pelibatan partisipatoris warga masyarakat merupakan cara pemberdayaan masyarakat 
agar penanganan perkara adopsi anak dan kekerasan dalam rumah tangga dapat berlangsung secara berkelanjutan.

Tabel 1:

Permasalahan dan Solusi

\begin{tabular}{|c|c|}
\hline $\begin{array}{c}\text { Permasalahan } \\
\text { yang ditemukan }\end{array}$ & Solusi yang ditawarkan \\
\hline $\begin{array}{l}\text { 1. Proses adopsi } \\
\text { anak dilakukan } \\
\text { berdasarkan } \\
\text { kebiasaan yang } \\
\text { berlaku di } \\
\text { masyarakat }\end{array}$ & $\begin{array}{l}\text { Pendampingan Pemerintah } \\
\text { Dusun untuk melakukan } \\
\text { sosialisasi prosedur adopsi } \\
\text { anak berdasarkan peraturan } \\
\text { perundangan yang berlaku }\end{array}$ \\
\hline $\begin{array}{l}\text { Kesadaran } \\
\text { masyarakat } \\
\text { masih rendah } \\
\text { mengenai } \\
\text { pentingnya } \\
\text { bukti formal } \\
\text { adopsi anak }\end{array}$ & $\begin{array}{l}\text { Motivasi dan sosialisasi } \\
\text { mengenai pentingnya } \\
\text { administrasi adopsi anak } \\
\text { bagi kepentingan anak, } \\
\text { keluarga, dan masyarakat }\end{array}$ \\
\hline $\begin{array}{l}\text { 3. } \\
\text { Ketidakjelasan } \\
\text { status anak } \\
\text { adopsi } \\
\text { menimbulkan } \\
\text { tindak } \\
\text { kekerasan } \\
\text { dalam rumah } \\
\text { tangga }\end{array}$ & $\begin{array}{l}\text { Peningkatan kesadaran } \\
\text { masyarakat bahwa hak } \\
\text { perlindungan bagi anak } \\
\text { adalah tanggungjawab } \\
\text { semua orang, bukan hanya } \\
\text { keluarga anak }\end{array}$ \\
\hline $\begin{array}{l}\text { 4. Penanganan } \\
\text { kasus } \\
\text { kekerasan } \\
\text { dalam rumah } \\
\text { tangga masih } \\
\text { belum sesuai } \\
\text { dengan } \\
\text { prosedur yang } \\
\text { berlaku }\end{array}$ & $\begin{array}{l}\text { Pendampingan pemerintah } \\
\text { dusun dan masyarakat } \\
\text { dalam menangani kasus } \\
\text { kekerasan dalam rumah } \\
\text { tangga }\end{array}$ \\
\hline
\end{tabular}

Metode yang digunakan untuk memberikan pemahaman yang utuh mengenai tata acara adopsi anak dan penanganan tindak kekerasan dalam rumah tangga adalah melakukan sosialisasi dan penyuluhan hukum dengan tema yang dimaksud. Disamping juga pendampingan dalam penanganan perkara, maka untuk kesinambungan dan keberlangsungan program, maka pembentukan Kader Pelindung Anak dan Satgas Anti KDRT.

Lembaga yang menjadi mitra Program KKN-PPM, adalah Pemerintah Dusun Kemiri. Dalam pelaksanaan Program KKN-PPM, Kepala Dusun Kemiri bersedia untuk mengeluarkan dana pendamping sebesar Rp. 1.000.00,00 (satu juta rupiah), dalam bentuk in cash dan in kind. Kondisi Dusun Kemiri dapat dilihat pada Gambar 1.

Gambar 1:

Denah Wilayah Padukuhan Kemiri

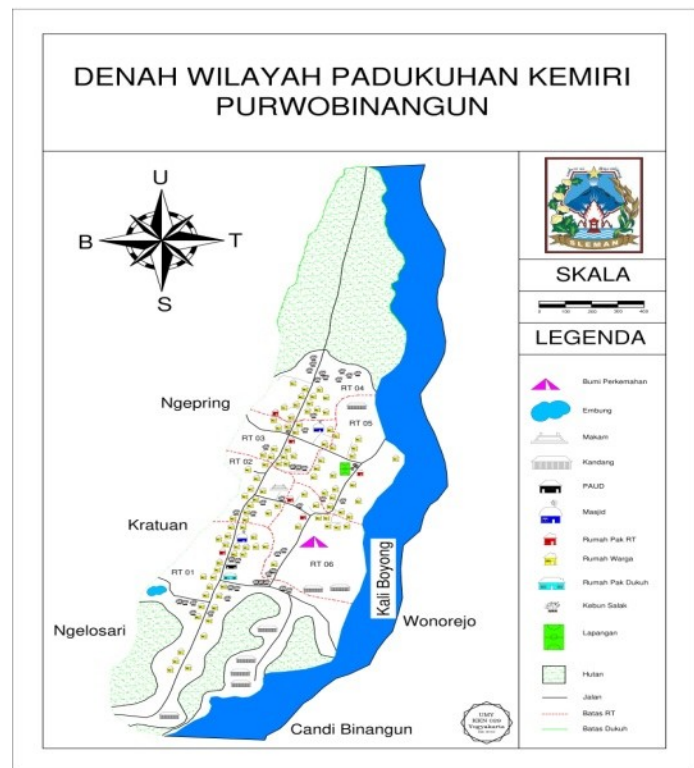

Sumber: Dokumen Dusun Kemiri.

\section{METODE}

Bagian ini ditulis dalam bahasa Metode yang digunakan untuk memberikan pemahaman yang utuh mengenai tat acara adopsi anak dan penanganan tindak kekerasan dalam rumah tangga adalah melakukan sosialisasi dan penyuluhan hukum dengan tema yang dimaksud. Disamping juga pendampingan dalam penanganan perkara, maka untuk kesinambungan dan keberlangsungan program, maka pembentukan Kader Pelindung Anak dan Satgas Anti KDRT. Metode pelaksanaan program dapat dilihat pada Gambar 2.

Uraian metode pelaksanaannya sbb:

1. Sosialisasi tata cara adopsi anak sesuai hukum Indonesia

a. Pembuatan materi sosialisasi (brosur) tentang tata cara adopsi anak

b. Penyebaran brosur tata cara adopsi anak

c. Sosialisasi tata cara adopsi anak dilaksanakan 
d. Sosialisasi penanggulangan kekerasan dalam rumah tangga (KDRT)

2. Pembuatan materi sosialisasi

3. Sosialisasi penanggulangan KDRT dilaksanakan

4. Pelatihan dan Pembentukan Kader
Pelindung Anak dan Satgas Anti KDRT

5. Pendampingan Penyelesaian Kasus Adopsi Anak dan Kasus KDRT.

Diagram 1:

Konsep Kegiatan KKN-PPM

Permasalahan yang ditemukan:

1. Proses adopsi anak dilakukan berdasarkan kebiasaan yang berlaku di masyarakat.

2. Kesadaran masyarakat masih rendah mengenai pentingnya bukti formal adopsi anak.

3. Ketidakjelasan status anak adopsi menimbulkan tindak kekerasan dalam rumah tangga

4. Penanganan kasus kekerasan dalam rumah tangga masih belum sesuai dengan prosedur yang berlaku

\section{Solusi yang ditawarkan:}

1. Pendampingan Pemerintah Dusun untuk melakukan sosialisasi prosedur adopsi anak berdasarkan peraturan perundangan yang berlaku

2. Motivasi dan sosialisasi mengenai pentingnya administrasi adopsi anak bagi kepentingan anak, keluarga, dan masyarakat

3. Peningkatan kesadaran masyarakat bahwa hak perlindungan bagi anak adalah tanggungjawab semua orang, bukan hanya keluarga anak

4. Pendampingan pemerintah dusun dan masyarakat dalam menangani kasus kekerasan dalam rumah tangga

Pemahaman Adopsi Anak, dilakukan dengan: Penyuluhan hukum mengenai Tata Cara Adopsi Anak berdasarkan peraturan perundangan dan Sosialisasi Gerakan Perlidungan Anak Terpadu

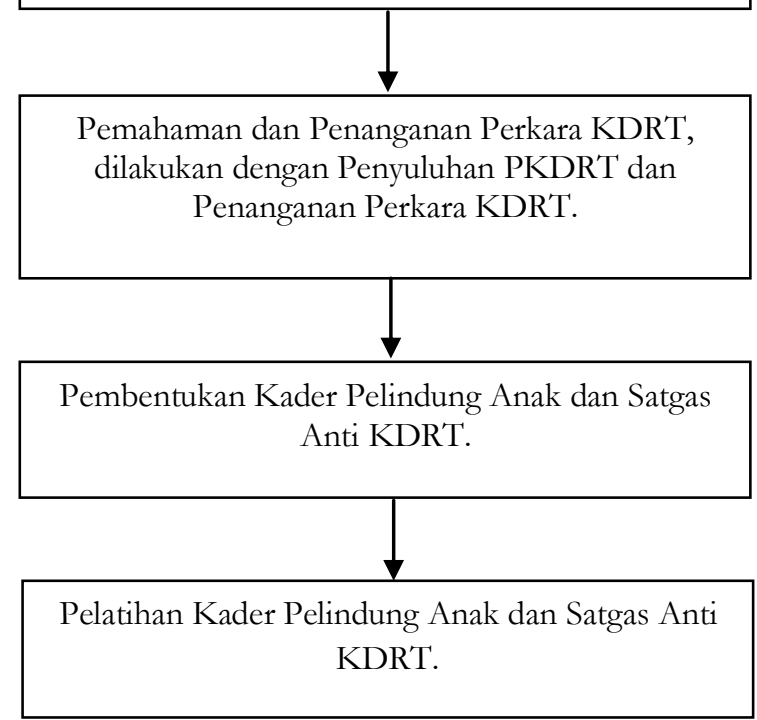




\section{HASIL DAN PEMBAHASAN}

\section{Sosialisasi Tata Cara Adopsi Sesuai} Hukum Indonesia

Kegiatan dilaksanakan berdasarkan pada keterangan yang disampaikan oleh Kepala Dusun Kemiri bahwasanya ada beberapa warga yang mengadopsi anak tanpa prosedur yang tepat sehingga dikhawatirkan dikemudian hari terjadi halhal yang tidak diinginkan sehingga tim perlu dilakukan kegiatan sosialisasi tatacara adopsi anak yang sesuai dengan hukumhukum yang ada dan berlaku. Permasalahan hukum yang akan terjadi pada anak adopsi yang tidak melalui prosedur resmi negara, antara lain: (1) anak adopsi mengalami kekerasan dalam rumah tangga, baik kekerasan fisik maupun kekerasan psikis, (2) anak adopsi akan mengalami kesulitan ketika akan menikah, terutama terjadi pada anak adopsi perempuan, mengingat ada ketentuan perwalian yang harus dipenuhi dalam sebuah pernikahan menurut Hukum Islam; dan (3) masalah waris dan hak waris anak adopsi akan terjadi apabila dalam kelaurga tidak secara tegas menetapkan pembagian waris mengacu pada hukum apa.

Tata cara adopsi anak telah diatur dalam Undang-Undang No. 35 Tahun 2014 perubahan atas Undang-Undang No. 23 Tahun 2002 tentang Perlindungan Anak. Di Indonesia, adopsi anak harus dilakukan secara legal berdasarkan Peraturan Pemerintah Republik Indonesia Nomor 54 Tahun 2007 tentang Pelaksanaan Pengangkatan Anak. Undang-undang ini bertujuan menjamin perlindungan hak-hak anak yang diadopsi. Persyaratan pengangkatan anak menurut Pasal 12 dan Pasal 13 Peraturan pemerintah Nomor 54 Tahun 2007 meliputi persyaratan anak yang akan diangkat dan persyaratan calon orang tua angkat.

Syarat anak yang akan diangkat, meliputi: (i) belum berusia 18 tahun, merupakan anak terlantar atau ditelantarkan, (ii) berada dalam asuhan keluarga atau lembaga pengasuh anak, dan (iii) memerlukan perlindungan khusus. Perlindungan khusus yang dimaksud adalah dalam situasi darurat, berasal dari kelompok minoritas/terisolasi, tereksploitasi secara ekonomi atau seksual, diperdagangkan, korban perlakuan salah dan penelantaran.

Usia anak angkat sebagaimana dimaksud di atas meliputi: (i) anak belum berusia 6 (enam) tahun, merupakan prioritas utama; (ii) anak berusia 6 (enam) tahun sampai dengan belum berusia 12 (dua belas) tahun, sepanjang ada alasan mendesak; dan (iii) anak berusia 12 (dua belas) tahun sampai dengan belum berusia 18 (delapan belas) tahun, sepanjang anak memerlukan perlindungan khusus.

Anak dapat diadopsi dari panti sosial atau panti asuhan yang telah memiliki izin resmi dari Kementrian Sosial dalam bidang pengangkatan anak.

Syarat calon orang tua angkat berdasarkan Peraturan Pemerintah Nomor 54 Tahun 2007, calon orangtua angkat harus memenuhi persyaratan sebagai berikut: (1) Sehat jasmani dan rohani, (2) berumur paling rendah 30 tahun dan paling tinggi 55 tahun; (3) memiliki agama yang sama dengan agama calon anak angkat. Jika asal usul anak tidak diketahui, maka agama disesuaikan dengan agama mayoritas penduduk setempat; (4) berkelakuan baik dan tidak pernah dihukum karena melakukan tindak kejahatan; (5) berstatus menikah paling singkat 5 tahun; (6) tidak merupakan pasangan sejenis; (7) tidak atau belum mempunyai anak atau hanya memiliki satu orang anak; (8) mampu secara ekonomi dan sosial, (9) memperoleh persetujuan anak dan izin tertulis orangtua atau wali anak; (10) membuat pernyataan tertulis bahwa pengangkatan anak adalah demi kepentingan terbaik bagi anak, kesejahteraan dan perlindungan anak; (11) adanya laporan sosial dari pekerja sosial setempat; (12) telah mengasuh calon anak angkat paling singkat 6 bulan, sejak izin pengasuhan diberikan; dan (13) memperoleh izin menteri dan/atau kepala 
instansi sosial.

Seseorang dapat mengangkat anak paling banyak 2 kali dengan jarak waktu paling singkat 2 tahun. Pengangkatan anak kembar dapat dilakukan sekaligus. Katerogori orang tua angkat yang dapat melakukan pengangkatan anaka ada dua, ayitu orang tua lengkap suami dan istri warga negara Indonesia; atau suami warga negara Indonesia dan istri warga negara asing.

Jenis Pengangkatan anak (adopsi) Indonesia yang dilakukan oleh Warga Negara Indonesia (WNI) ada empat yaitu: (1) pengangkatan Anak antar warga negara Indonesia (Domestic Adoption); pengangkatan Anak secara langsung (Private Adoption); (3) pengangkatan Anak oleh Orang Tua Tunggal (Single Parent); dan (4) pengangkatan Anak menurut Hukum Adat.

Pengangkatan anak harus disampaikan kepada Dinas Sosial di Pemerintah Daerah, dan harus mendapatkan ijin Kepala Dinas Sosial/Instansi Sosial baik di pemda Propinsi atua Kabupaten/Kota. Berdasarkan Surat Edaran Mahkamah Agung No. 6 Tahun 1983 tentang Penyempurnaan Surat Edaran No. 2 Tahun 1979 mengenai Pengangkatan Anak, pengangkatan anak harus ditetapkan oleh Pengadilan Negeri. Pengadilan Negeri yang dimaksud adalah Pengadilan Negeri tempat anak yang akan diangkat itu berada. Selain Pengadilan Negeri, Pengadilan Agama juga dapat memberikan penetapan anak berdasarkan hukum Islam berdasarkan Undang-Undang Nomor 3 tahun 2006 tentang Peradilan Agama. Pengadilan akan memberikan penetapan apabila calon orang tua angkat dapat meyakinkan bahwa calon orang tua secara sosial dan ekonomis, moril maupun materiil mampu menjamin kesejahteraan anak yang akan diangkat.

Terdapat ketentuan yang lain dalam hal pengangkatan anak, sebagaimana diatur dalam Staatblaad 1917 No. 129 yang mengatur bahwa pengangkatan anak yang hanya dimungkinkan untuk anak laki-laki dan hanya dapat dilakukan dengan Akta Notaris. Staatblaad 1917 No. 129 mengatur tentang pengangkatan anak bagi orang-orang Tionghoa yang, selain memungkinkan pengangkatan anak oleh seseorang yang terikat perkawinan, juga bagi yang pernah terikat perkawinan (duda atau janda). Namun bagi janda yang suaminya telah meninggal dan sang suami meninggalkan wasiat yang isinya tidak menghendaki pengangkatan anak, maka janda tersebut tidak dapat melakukannya.

Pengangkatan anak menurut Staatblaad 1917 No. 129 hanya dimungkinkan untuk anak laki-laki dan hanya dapat dilakukan dengan Akte Notaris. Namun, berdasarkan Yurisprudensi Putusan Pengadilan Negeri Istimewa Jakarta tertanggal 29 Mei 1963, telah membolehkan mengangkat anak perempuan.

Di Indonesia perihal pewarisan untuk anak adopsi ada tiga hukum yang berlaku, yakni (1) hukum adat; (2) hukum barat; dan (3) hukum Islam. Ketiga sistem hukum tersebut memiliki ketentuan yang berbeda dalam hal pewarisan anak. Menurut Hukum Adat, penentuan waris bagi anak angkat menurut hukum adat Jawa (menganut sistem parental) menentukan bahwa pengangkatan anak tidak otomatis memutuskan tali keluarga antara anak itu dengan orangtua kandungnya. Anak adopsi selain mendapatkan hak waris dari orangtua angkatnya, juga tetap berhak atas waris dari orang tua kandungnya. (M. Buddiarto, 1991).

Sedangkan pewarisan anak adopsi menurut Hukum Islam, pengangkatan anak tidak membawa akibat hukum dalam hal hubungan darah, hubungan wali-mewali dan hubungan waris mewaris dengan orang tua angkat. Anak adopsi tetap menjadi ahli waris dari orang tua kandungnya dan anak tersebut tetap memakai nama dari ayah kandungnya (M. Budiarto, 1991).

Menurut Hukum Barat sebagaimana diatur dalam Staatblaad 1917 
No. 129, akibat hukum dari pengangkatan anak adalah anak tersebut secara hukum memperoleh nama dari bapak angkat, dijadikan sebagai anak yang dilahirkan dari perkawinan orang tua angkat dan menjadi ahli waris orang tua angkat. Artinya, akibat pengangkatan tersebut maka terputus segala hubungan perdata, yang berpangkal pada keturunan karena kelahiran, yaitu antara orang tua kandung dan anak tersebut.

Sosialisasi ini sangat penting bagi warga Dusun Kemiri, sehingga di kemudian hari dapat memahami tatacara adopsi anak, dan diharapkan ke depan warga Dusun Kemiri melakukan proses adopsi sesuai dengan peraturan perundangundangan yang berlaku di Indonesia, sebagaimana telah diatur dalam UndangUndang No. 35 Tahun 2014 perubahan atas Undang-Undang No. 23 Tahun 2002 tentang Perlindungan Anak. Di Indonesia, adopsi anak harus dilakukan secara legal berdasarkan Peraturan Pemerintah Republik Indonesia Nomor 54 Tahun 2007 tentang Pelaksanaan Pengangkatan Anak. Kedua peraturan perundang-undangan tersebut di atas ditetapkan dengan tujuan menjamin perlindungan hak - hak anak yang diadopsi.

Faktor pendukung dari program ini adalah informasi yang didapat dari kepala dukuh serta beberapa informasi yang didapat dari warga mengenai adopsi anak yang pernah terjadi di Dusun Kemiri. Sedangkan faktor yang menghambat pelaksanaan program ini adalah warga yang mungkin sensitif dengan materi yang akan disampaikan sehingga tidak banyak warga yang datang dalam sosialisasi tersebut dan tidak meratanya informasi kepada semua warga tentang tata cara adopsi anak yang baik dan benar sesuai dengan hukum yang berlaku. Materi sosialisasi diberikan dalam bentuk leaflet seperti terlihat pada Gambar 3. Dokumen kegiatan dapat dilihat pada Gambar 4.

Gambar 3:

Brosur Tata Cara Adopsi Anak

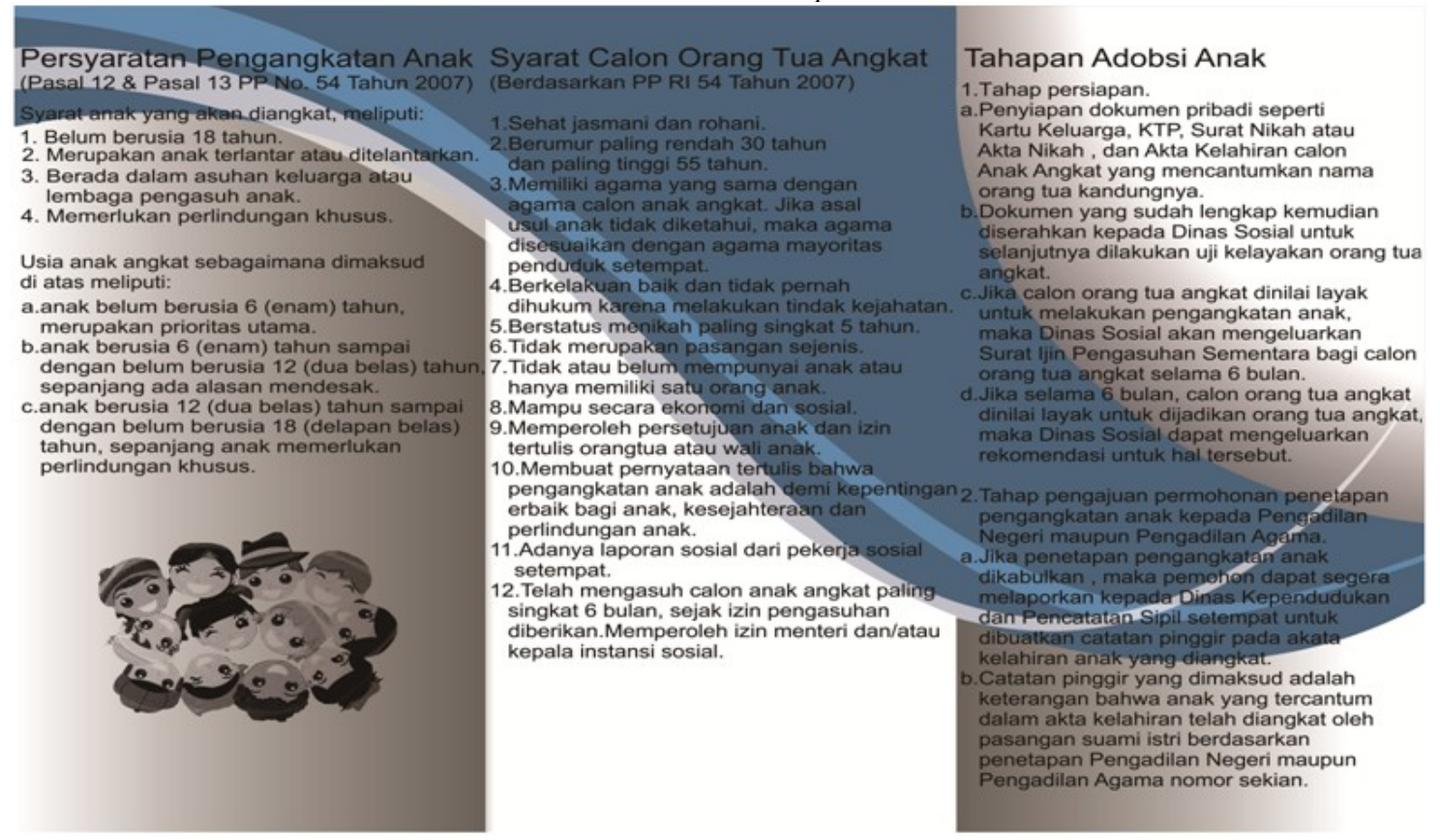


Gambar 4:

Sosialisasi Tatacara Adopsi Anak

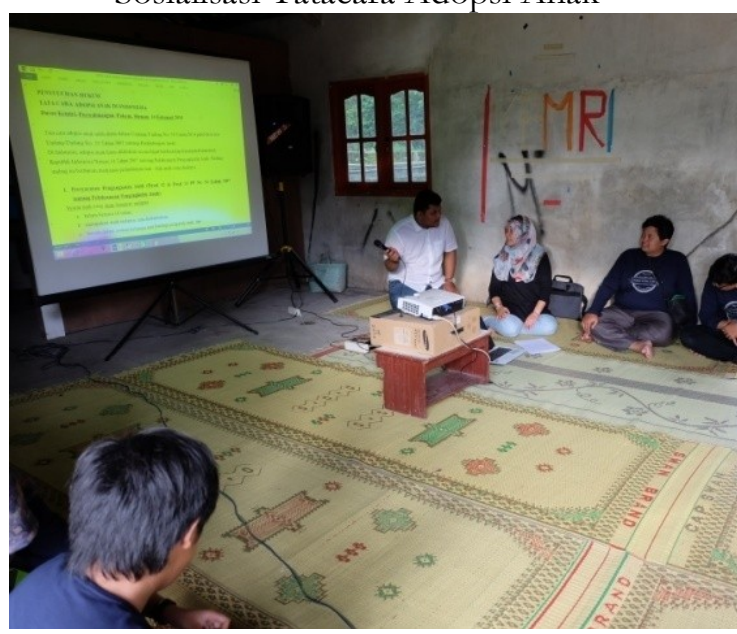

Sumber: Dokumen pribadi

\section{Sosialisasi penanggulangan Kekerasan Dalam Rumah Tangga (KDRT)}

Kegiatan dilakukan dilandasi fakta bahwasanya ada beberapa warga Dusun Kemiri yang menjadi korban dan pelaku KDRT. Kecederungan untuk menjadi korban dan pelaku KDRT menjadi hal sangat mengkhawatirkan, dan perlu segera diantisipasi dan ditangani, mengingat sehingga dikhawatirkan dikemudian hari terjadi hal-hal yang tidak diinginkan sehingga perlu dilakukan kegiatan sosialisasi penanggulangan kekerasan dalam rumah tangga (KDRT). Menurut pemaparan Kepala Dusun Kemiri, pemahaman warga masyarakat Dusun Kemiri akan KDRT sangat minim, mengingat tingkat Pendidikan masyarakat yang masih rendah dan warga masyarakat menganggap bahwa kekerasan yang terjadi dalam rumah tangga adalah hal yang lumrah dan kalaupun terjadi kekerasan fisik yang berat makan warga masyarakat selain keluarga tidak berhak untuk terlibat menyelesaikannya, dengan pemahaman yang seperti ini, maka seringkali kasus KDRT yang terjadi dibiarkan begitu saja, tanpa ada upaya penyelesian baik dari pihak keluarga maupun masyarakat.

Sebenarnya apabila dikaji dari definisi kekerasan dalam Rumah Tangga menurut Undang-Undang Nomor 23
Tahun 2004 tentang Penghapusan Kekerasan Dalam Rumah Tangga, KDRT tidak hanya perbuatan yang telah dilakukan melainkan juga perbuatan permulaan seperti ancaman untuk melakukan perbuatan, pemaksaan atau perampasan kebebasan seseorang sudah dapat dikatakan KDRT. Sebagaimana ditetapkan dalam Pasal 1 UU No. 23 Tahun 2004 bahwa KDRT adalah setiap perbuatan terhadap seseorang terutama perempuan, yang berakibat timbulnya kesengsaraan atau penderitaan secara fisik, seksual, psikologis, dan/atau penelantaran rumah tangga termasuk ancaman untuk melakukan perbuatan, pemaksaan, atau perampasan kemerdekaan secara melawan hukum dalam lingkup rumah tangga. Berdasarkan pasal tersebut maka KDRT yang dilakukan dalam lingkup rumah tangga dapat dilakukan dengan cara: (i) kekerasan fisik; (ii) kekerasan psikis; (iii) kekerasan seksual; atau (iv) penelantaran rumah tangga. Bentuk-bentuk kekerasan ini merupakan gambaran kekerasan yang sering terjadi dalam rumah tangga dan menjadi fenomena umum di tengah masyarakat.

Korban adalah orang yang mengalami kekerasan dan/atau ancaman kekerasan dalam lingkup rumah tangga. Pasal 10 UU No. 23 Tahun 2004 menetapkan bahwa korban berhak mendapatkan: (i) perlindungan dari pihak keluarga, kepolisian, kejaksaan, pengadilan, advokat, lembaga sosial, atau pihak lainnya baik sementara maupun berdasarkan penetapan perintah perlindungan dari pengadilan; (ii) pelayanan kesehatan sesuai dengan kebutuhan medis; (iii) penanganan secara khusus berkaitan dengan kerahasiaan korban; (iv) pendampingan oleh pekerja sosial dan bantuan hukum pada setiap tingkat proses pemeriksaan sesuai dengan ketentuan peraturan perundang-undangan; dan (v) pelayanan bimbingan rohani.

Ketentuan tersebut diatas menegaskan kembali bahawa KDRT bukan hanya merupakan domain privat, dalam arti hanya menjadi tanggung jawan keluarga, 
melainkan juga domain publik yakni menjadi tanggung jawab masyarakat untuk mencegah dan melindungi serta mendampingi korban. Korban KDRT memerlukan upaya pemulihan yang harus dilakukan oleh pihak di luar keluarga. Kewajiban Masyarakat dalam hal penanganan kasus KDRT adalah bahwa setiap orang yang mendengar, melihat, atau mengetahui terjadinya kekerasan dalam rumah tangga wajib melakukan upayaupaya sesuai dengan batas kemampuannya untuk: (i) mencegah berlangsungnya tindak pidana; (ii) memberikan perlindungan kepada korban; (iii) memberikan pertolongan darurat; dan (iv) membantu proses pengajuan permohonan penetapan perlindungan.

Untuk kepentingan pemulihan, korban dapat memperoleh pelayanan dari tenaga kesehatan; pekerja sosial; relawan pendamping; dan/atau pembimbing rohani. Dalam memberikan pelayanan, pekerja sosial harus dapat melakukan konseling untuk menguatkan dan memberikan rasa aman bagi korban; memberikan informasi mengenai hak-hak korban untuk mendapatkan perlindungan dari kepolisian dan penetapan perintah perlindungan dari pengadilan; mengantarkan korban ke rumah aman atau tempat tinggal alternatif; dan melakukan koordinasi yang terpadu dalam memberikan layanan kepada korban dengan pihak kepolisian, dinas sosial, lembaga sosial yang dibutuhkan korban.

Tenaga kesehatan wajib memeriksa korban sesuai dengan standar profesinya. Dalam hal korban memerlukan perawatan, tenaga kesehatan wajib memulihkan dan merehabilitasi kesehatan korban. Sementara pekerja sosial, relawan pendamping, dan/atau pembimbing rohani wajib memberikan pelayanan kepada korban dalam bentuk pemberian konseling untuk menguatkan dan/atau memberikan rasa aman bagi korban. Dalam rangka pemulihan terhadap korban, tenaga kesehatan, pekerja sosial, relawan pendamping dan/atau pembimbing rohani dapat melakukan kerja sama.

Selain terkandung kewajiban masyarakat untuk mencegah terjadinya KDRT, dan melindungi setiap korban KDRT, UU No. 23 Tahun 2004 juga menentukan adanya kewajiban pemerintah, misalnya untuk penyelenggaraan pelayanan terhadap korban, pemerintah dan pemerintah daerah sesuai dengan fungsi dan tugas masing-masing dapat melakukan upaya-upaya sebagai berikut: (i) penyediaan ruang pelayanan khusus di kantor kepolisian; (ii) penyediaan aparat, tenaga kesehatan, pekerja sosial, dan pembimbing rohani; (iii) pembuatan dan pengembangan sistem dan mekanisme kerja sama program pelayanan yang melibatkan pihak yang mudah diakses oleh korban; dan (iv) memberikan perlindungan bagi pendamping, saksi, keluarga, dan teman korban.

Jenis-jenis kekerasan yang dapat terjadi dalam rumah tangga terhadap orang dalam lingkup rumah tangga menurut Pasal 5 UU No. 23 Tahun 2004, antara lain dapat dilakukan dengan cara: (1) kekerasan fisik; (2) kekerasan psikis; (3) kekerasan seksual; atau (4) penelantaran rumah tangga. UU No. 23 tahun 2004 menjelaskan lebih lanjut yang dimaksud dengan kekerasan fisik adalah perbuatan yang mengakibatkan rasa sakit, jatuh sakit, atau luka berat (Pasal 6 UU PKDRT). Bentuk-bentuk kekerasan fisik yang dialami perempuan/korban mencakup, antara lain: tamparan, pemukulan, penjambakan, penginjakinjakan, penendangan, pencekikan, lemparan benda keras, penyiksaan menggunakan benda tajam, seperti pisau, gunting, setrika serta pembakaran. Sementara yang dimaksud dengan kekerasan psikis menurut Pasal 7 UU No. 23 Tahun 2004 adalah perbuatan yang mengakibatkan ketakutan, hila ngnya rasa percaya diri, hilangnya kemampuan untuk bertindak, rasa tidak berdaya, dan/atau penderitaan psikis berat pada seseorang. Bentuk kekerasan secara psikologis yang 
dialami perempuan mencakup makian, penghinaan yang berkelanjutan untuk mengecilkan harga diri korban, bentakan dan ancaman yang dimaksudkan untuk memunculkan rasa takut.

Kekerasan Seksual menurut Pasal 8 UU No. 23 Tahun 2004 Kekerasaan meliputi: pemaksaan hubungan seksual yang dilakukan terhadap orang yang menetap dalam lingkup rumah tangga tersebut; dan pemaksaan hubungan seksual terhadap salah seorang dalam lingkup rumah tangganya dengan orang lain untuk tujuan komersial dan/atau tujuan tertentu. Kekerasan seksual termasuk berbagai perilaku yang tak diinginkan dan mempunyai makna seksual (pelecehan seksual), maupun berbagai bentuk pemaksaan hubungan seks yang disebut sebagai pemerkosaan. Kekerasan seksual, meliputi: pemaksaan hubungan seksual dengan pola yang tidak dikehendaki atau disetujui oleh istri, pemaksaan hubungan seksual ketika istri tidak menghendaki, istri sedang sakit atau menstruasi.

Sedangkan yang dimaksud dengan penelantaran Rumah Tangga menurut Pasal 9 UU No. 23 Tahun 2004 antara lain: (1) Setiap orang dilarang menelantarkan orang dalam lingkup rumah tangganya, padahal menurut hukum yang berlaku baginya atau karena persetujuan atau perjanjian ia wajib memberikan kehidupan, perawatan, atau pemeliharaan kepada orang tersebut. (2) Penelantaran yang dimaksud sebelumnya juga berlaku bagi setiap orang yang mengakibatkan ketergantungan ekonomidengan cara membatasi dan/atau melarang untuk bekerja yang layak di dalam atau di luar rumah sehingga korban berada di bawah kendali orang tersebut. Kekerasan ekonomi, meliputi: tidak memberi nafkah pada istri, menelantarkan, atau memanfaatkan ketergantungan istri secara ekonomis untuk mengontrol kehidupan istri, membiarkan istri bekerja kemudian penghasilannya dikuasai oleh suami (Robby Yahya Rumalutur, 2016).

Kekerasan dalam Rumah Tangga
(KDRT), jenis kekerasan yang termasuk KDRT adalah: (i) Kekerasan Terbuka (overt) berupa kekerasan fisik yang dapat dilihat, seperti perkelahian, pukulan, tendangan, menjambak, mendorong, sampai pada membunuh. (ii) Kekerasan Tertutup (covert) berupa kekerasan psikis atau emosional. Kekerasan ini sifatnya tersembunyi, seperti ancaman, hinaan, atau cemooh yang kemudian menyebabkan korban susah tidur, tidak percaya diri, tidak berdaya, terteror, dan memiliki keinginan bunuh diri. (iii) Kekerasan Seksual merupakan kekerasan yang dilakukan untuk memuaskan hasrat seks (fisik) dan verbal (fisik). Secara fisik misalnya pelecehan seksual (meraba, menyentuh organ seks, mencium paksa, memaksa berhubungan seks dengan pelaku atau orang ketiga, memaksa berhubungan intim. Sedangkan verbal seperti membuat komentar, julukan, atau gurauan porno yang sifatnya mengejek, juga membuat ekspresi wajah, gerakan tubuh, atau pun perbuatan seksual lain yang sifatnya melecehkan dan atau menghina korban. (iv) Kekerasan Finansial dapat dilakukan dalam bentuk eksploitasi, memanipulasi, dan mengendalikan korban dengan tujuan finansial. Serta memaksa korban bekerja, melarang korban bekerja tapi menelantarkannya, atau mengambil harta pasangan tanpa sepengetahuannya ("4 Jenis Kekerasan yang Termasuk KDRT Kompas.com", 2014).

KDRT dikategorikan dalam 2 delik yaitu delik biasa dan delik aduan. Delik adalah suatu tindakan melanggar hukum yang telah dilakukan dengan sengaja ataupun tidak sengaja oleh seseorang yang dapat dipertanggungjawabkan atas tindakannya dan oleh Undang-undang telah dinyatakan sebagai suatu tindakan atau perbuatan yang dapat dihukum ("Pengertian Delik Biasa dan Delik Aduan, 2013). Delik biasa atau kriminal murni, yaitu semua tindak pidana yang terjadi dan tidak bisa dihentikan prosesnya dengan alasan yang bisa dimaklumi. Misalnya penipuan. Meskipun korban sudah 
memaafkan atau pelaku mengganti kerugian, proses hukum terus berlanjut sampai vonis karena ini merupakan delik murni yang tidak bisa dicabut. Dalam delik biasa perkara tersebut dapat diproses tanpa adanya persetujuan dari yang dirugikan (korban). Jadi, walaupun korban telah mencabut laporannya kepada pihak yang berwenang, penyidik tetap berkewajiban untuk memproses perkara tersebut. Delik aduan adalah perbuatan pidana yang hanya dapat diproses secara hukum apabila orang yang dirugikan melakukan pengaduan kepada yang berwajib, tanpa pnegaduan dari korban atau orang yang dirugikan karena delik/perbuatan tersbut tidak dapat diproses. Dalam delik aduan suatu aduan dapat ditarik atau dicabut apabila ada perdamaian ataupun kesepakatan antara sipembuat delik dan korban yang dirugikan (Hukum online, 2013).

Diharapkan, dengan adanya sosialisasi ini warga Dusun Kemiri dapat lebih menjaga keluarganya dan terhindar dari KDRT. Sebagaimana dianyatakan dalam Undang-Undang Nomor 23 Tahun 2004 tentang Perlindungan Kekerasan Dalam Rumah Tangga, bahwasannya kekerasan dalam Rumah Tangga adalah setiap perbuatan terhadap seseorang terutama perempuan, yang berakibat timbulnya kesengsaraan atau penderitaan secara fisik, seksual, psikologis, dan/atau penelantaran rumah tangga termasuk ancaman untuk melakukan perbuatan, pemaksaan, atau perampasan kemerdekaan secara melawan hukum dalam lingkup rumah tangga. Setiap anggota keluarga memiliki potensi untuk menjadi pelaku ataupun korban, misalnya suami, isteri, dan anak. Akan tetapi UU No. 23 Tahun 2004 memperluas makna anggota keluarga dengan menyatakan bahwa anggota keluarga inti yakni suami, isteri, dan anak, akantetapi juga termasuk orang-orang yang mempunyai hubungan keluarga dengan anggota keluarga inti karena hubungan darah, perkawinan, persusuan, pengasuhan, dan perwalian, yang menetap dalam rumah tangga; dan/atau orang yang bekerja membantu rumah tangga dan menetap dalam rumah tangga tersebut.

Sosialisasi ini dimaksudkan untuk meningkatkan kesadaran sosial dan kesadaran hukum masyarakat bahwa KDRT adalah bukan masalah domestik keluarga, melainkan juga masalah sosial atau masyarakat. Anggota masyarakat dapat melaporkan dan mencegah terjadinya KDRT dalam sebuah keluarga. Korban, dalam arti orang yang mengalami kekerasan dan/atau ancaman kekerasan dalam lingkup rumah tangga, secara hukum berhak mendapatkan: (a) perlindungan dari pihak keluarga, kepolisian, kejaksaan, pengadilan, advokat, lembaga sosial, atau pihak lainnya baik sementara maupun berdasarkan penetapan perintah perlindungan dari pengadilan; (b) pelayanan kesehatan sesuai dengan kebutuhan medis; (c) penanganan secara khusus berkaitan dengan kerahasiaan korban; (d) pendampingan oleh pekerja sosial dan bantuan hukum pada setiap tingkat proses pemeriksaan sesuai dengan ketentuan peraturan perundang-undangan; dan (e) pelayanan bimbingan rohani.

Faktor pendukung dari program ini adalah informasi yang didapat dari kepala dukuh serta beberapa informasi yang didapat dari warga mengenai KDRT yang pernah terjadi di Dusun Kemiri. Faktor yang menghambat pelaksanaan program ini adalah warga yang mungkin sensitif dengan materi yang akan disampaikan sehingga tidak banyak warga yang datang dalam sosialisasi tersebut dan tidak meratanya informasi kepada semua warga. Dokumen penyuluhan hukum KDRT dapat dilihat pada Gambar 5. 
Gambar 5:

Penyuluhan Hukum Kekerasan Dalam Rumah Tangga

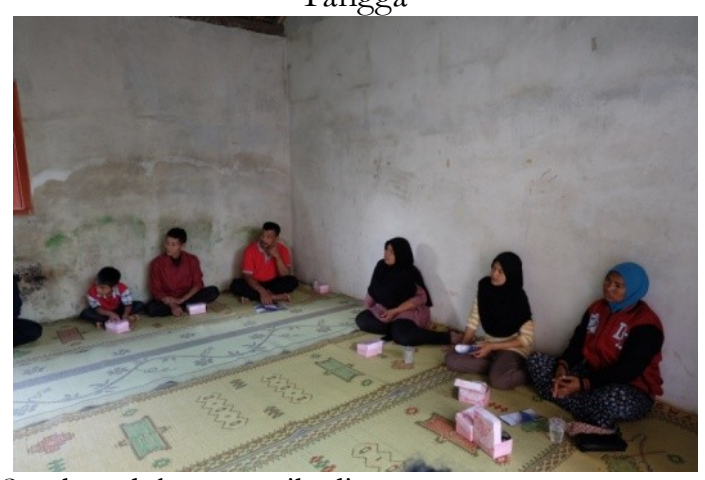

Sumber: dokumen pribadi

\section{Pembentukan Kader Pelindung Anak dan Satgas Anti KDRT}

Pembentukan Kader Pelindung Anak dan Satgas Anti KDRT dilakukan sebagai upaya memenuhi amanat UU No. 23 Tahun 2004 dalam hal melaksanakan kewajiban masyarakat untuk mencegah terjadinya KDRT, dan melindungi setiap korban KDRT. Sebagaimana diketahui bahwa korban KDRT memerlukan upaya pemulihan, maka sudah menjadi tugas bagi masyarakat pada umumnya, dan Satgas Anti KDRT khususnya untuk melakukan penanganan terhadap korban KDRT sesegera mungkin apabila mendengar, melihat, atau mengetahui terjadinya KDRT. Penanganan yang dilakukan oleh Satgas Anti KDRT antara mencegah berlangsungnya tindak pidana; memberikan perlindungan kepada korban; dan memberikan pertolongan darurat. Selanjutnya Satgas Anti KDRT dapat membantu proses pengajuan permohonan penetapan perlindungan.

Pembentukan Kader ini dibentuk selain untuk melakukan penanganan korban KDRT dan mencegah terjadinya kasus KDRT, juga dimaksudkan untuk melakukan sosialisasi dan pemantauan perkembangan yang terjadi di masalah KDRT di Dusun Kemiri. Kader telah terbentuk dengan beranggotakan 10 wanita kader dusun dibawah pimpinan Ibu Dusun Kemiri. Tugas kader antara lain; (1) melakukan sosialisasi tentang perlindungan anak dan KDRT; (2) memantau perkembangan pemahaman masyarakat mengenai perlindungan anak dan KDRT; (3) melakukan pendampingan bagi korban KDRT; (4) melakukan penanganan awal korban KDRT; dan (5) menjaga kerahasiaan korban KDRT. Dokumen pembentukan Kader Pelindung Anak dan Satgas Anti KDRT dapat dilihat pada gambar 6 .

Gambar 6:

Pembentukan Kader Pelindung Anak dan Satgas KDRT

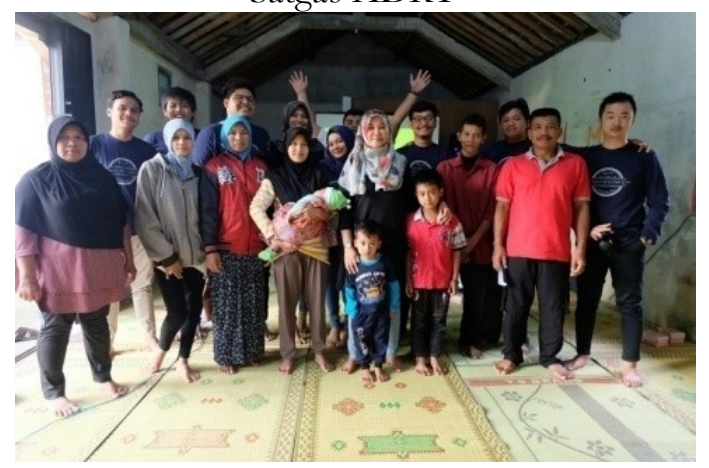

Sumber: Dokumen pribadi

\section{Pendampingan Tim Penyelesaian Kasus Adopsi Anak dan Kasus KDRT}

Pendampingan terhadap Kader Pelindung Anak dan Satgas Anti KDRT dilakukan untuk memantapkan peran mereka di masyarakat, serta memberikan contoh penanganan awal kasus KDRT beserta tindak lanjutnya. Pendampingan dilakukan selama dua minggu pertama, dengan melihat perkembangan penanganan kasus KDRT dan Adopsi Anak.

Kasus Adopsi Anak di Dusun Kemiri terjadi di 5 keluarga dengan berbagai sebab dan alasan yang berbeda untuk melakukan adopsi. Perbedaan alasan inilah yang sebenarnya memicu terjadinya kasus kekerasan terhadap anak adopsi, baik pelakunya dari internal keluarga orang tua angkat maupun dari masyarakat. Anak adopsi yang tidak diketahui dengan jelas siapa ayah kandungnya, sangat rentan terhadap kekerasan psikis yang dilakukan oleh masyarakat. Kader melakukan pendampingan dan perlindungan yang 
cukup inten terhadap anak tersebut.

Kasus KDRT ditemukan 60 kasus. Kader telah berhasil melakukan pendekatan dan penanganan terhadap 10 kasus yang terjadi pada 10 keluarga. Permasalahan yang dihadapi oleh Kader dalam melakukan penanganan kasus KDRT adalah masyarakat menganggap bahwa KDRT adalah masalah internal keluarga, sehingga tidak diperlukan orang di luar anggota keluarga untuk mengetahui atau bahkan turut menyelesaikannya. Hal ini menyebabkan masih banyak kasus KDRT yang berlum tertangani secara baik, karena pihak keluarga sangat tertutup dan tidak mengijinkan pihak luar untuk melakukan intervensi. Akantetapi Kader tetap melaksanakan tugasnya dan terus melakukan pendekatan terhadap keluargakeluarga tersebut.

\section{KESIMPULAN}

Kesimpulan yang dapat diambil dari pelaksanaan Kuliah Kerja Nyata di Dusun Kemiri, Desa Purwobinangun, Kecamatan Pakem, Kabupaten Sleman adalah semua program kegiatan yang direncanakan telah terealisasi dengan baik dan sesuai dengan jadwal dan rancangan yang telah ditentukan. Permasalahan adopsi anak sudah terpecahkan melalui beberapa tahap pengabdian. Demikian halnya dengan penanganan Kasus KDRT. Pengabdian ini telah memberikan pemahaman yang komprehensif mengenai tata cara adopsi anak dan perlindungan KDRT. Pemahaman hukum dan ksedaran hukum mulai meningkat dan terjaga, karena senantiasa ada Kader Perlindungan Anak dan Satgas Anti KDRT yang aktif melakukan sosialisasi dan upaya-upaya penyadaran sosial bagi masyarakat.

\section{Saran}

Saran yang dapat disampaikan berdasarkan pelaksanaan pengabdian ini antara lain:

1. Bagi Warga masyarakat Dusun Kemiri sebaiknya lebih peduli terhadap dokumen-dokumen keluarga yang belum benar sesuai hukum yang berlaku di Indonesia agar lebih memudahkan anak dalam pengurusan Kartu Identitas Anak dan lebih memberikan perlidungan hukum bagi anak.

2. Pemerintah Dusun Kemiri dan warga masyarakat sebaiknya selalu melakukan sosialisasi agar kasus adopsi anak dan KDRT dapat dikurangi di Dusun Kemiri.

\section{UCAPAN TERIMA KASIH}

Penulis mengucapkan terima kasih yang sebesar-besarnya kepada para pihak yang telah berkontribusi hingga pengabdian ini dapat dilaksanakan, antara lain kepada:

1. Pemerintah Desa Puwobinangun, Pakem, Sleman

2. Pemerintah Dusun Kemiri, Purwobinangun, Pakem, Sleman

3. Universitas Muhammadiyah Yogyakarta

4. Lembaga Pendidikan, Penelitian, dan pengabdian pada Masyarakat (LP3M) Universitas Muhammadiyah Yogyakarta 


\section{DAFTAR PUSTAKA}

Budiarto, M. (1991). Pengangkatan Anak ditinjau dari segi Hukum. Akademika Pressindo.

Mahkamah Agung Republik Indonesia. (1983). Surat Edaran Mahkamah Agung No. 6 Tahun 1983 tentang Penyempurnaan Surat Edaran No. 2 Tahun 1979 mengenai Pengangkatan Anak.

Pengertian Delik Biasa dan Delik Aduan hukumonline.com. (n.d.). Retrieved December 23, 2013, dari https://www.hukumonline.com/klinik /detail/lt4f9bb33933005/pengertiandelik-biasa-dan-delik-aduan

Presiden Republik Indonesia. (2002). Undang-undang Republik Indonesia Nomor 23 tahun 2002 tentang Perlindungan Anak. Kementerian Pemberdayaan Perempuan, Republik Indonesia.

Presiden Republik Indonesia. (2002). Undang-Undang Nomor 23 Tahun 2002 tentang Perlindungan Anak.

Presiden Republik Indonesia. (2004) Undang-Undang Republik Indonesia Nomor 23 Tahun 2004 tentang Penghapusan Kekerasan Dalam Rumah Tangga.

Presiden Republik Indonesia. (2007) Peraturan pemerintah Nomor 54 Tahun 2007 tentang Pengangkatan Anak.

Presiden Republik Indonesia. (2009) Peraturan Menteri Sosial Nomor 110 Tahun 2009 tentang Persyaratan Pengangkatan Anak.

Rumalutur, R. Y. (2016). Bentuk-bentuk Kekerasan Dalam Rumah Tangga Menurut UU KDRT - LBH PEKA Lembaga Bantuan Hukum Pemberdayaan Masyarakat Untuk Keadilan. Diambil pada 10 September 2016, dari http://www.lbhpeka.or.id/2016/09/b entuk-bentuk-kekerasan-dalam- rumah 4.html.

4 Jenis Kekerasan yang Termasuk KDRT Kompas.com. (n.d.). Diambil pada 12 Oktober 2016, dari https://lifestyle.kompas.com/read/20 14/10/12/230000220/4.Jenis.Kekeras an.yang.Termasuk.KDRT. 